\title{
Socially Marginalised Women in Selected Narratives of Egyptian Female Writers
}

\begin{abstract}
Since the 1970s women authors in Egypt have produced a number of narratives that centre on the plight and fate of socially marginalised women. In this context marginalisation is not only understood in the sense of socio-economically disadvantaged women of the lower strata but also refers to non-conformist women, whose behaviour is considered to be deviant from the norm, abnormal or even mad by mainstream society. As a result, they feel alienated from society, and choose diverse ways (passive, active, or subversive) of coping with their fate. This contribution will take selected novels and short stories written by Alifa Rifaat (1930-96), Nawal El Saadawi (b. 1931), and Salwa Bakr (b. 1949) as examples in order to demonstrate the shift in emphasis and perspective on the topic. This will be done against the individual biographical background and writing career of the three authors. Although all authors are committed to women's issues and gender equality, not all of them can be described as feminist writer-activists.
\end{abstract}

Keywords: Egyptian women writers, Alifa Rifaat, Nawal El Saadawi, Salwa Bakr, social marginalisation, alienation, literary perspectives

\section{Introduction: Social Marginalisation as a Major Topic of Egyptian Women} Authors

Since the 1970s women authors in Egypt have produced a number of narratives that centre on the plight and fate of socially marginalised women. In this context marginalisation is not only understood in the sense of socio-economically disadvantaged women of the lower strata who suffer discrimination because of their sex and class affiliation and are often prevented from developing their own identity. It also refers to non-conformist women, whose behaviour is considered to be deviant from the norm, abnormal or even mad by mainstream society. As a result, they feel alienated from society, and choose diverse ways (passive, active, or sub- 
versive) of coping with their fate. ${ }^{1}$ At times both forms of marginalisation are intertwined in a kind of double marginalisation. This contribution will take selected novels and short stories written by Alifa Rifaat (1930-96), Nawal El Saadawi (b. 1931), and Salwa Bakr (b. 1949) as examples. All writers are well-known faces in the Egyptian and Arab literary scene, though Saadawi is perhaps the best-known to a wider public. A number of their publications have been translated into English, German, and other languages, and quite a lot of studies on their lives and works have been published. On the basis of these translations and research studies, this article will focus on the shift in emphasis and perspective in dealing with the topic of social marginalisation of women. This will be done against the individual biographical background and writing career of the three authors.

All three writers can be described as socially committed authors as their intention is to raise consciousness and ultimately provoke change. Their socialand gender-conscious pen highlights the sufferings and oppression of women in societies that differentiate between the man's world and woman's domain, but also speaks about their wishes, desires, and yearnings. The ideological positions and stylistic approaches of the writers may vary. However, their stories obviously express dissatisfaction with socio-cultural norms and attitudes, particular those related with women and their place in society. By giving marginalised women a voice they present an alternative narrative to the dominant gender discourse and thereby challenge and question the underlying system of morals and values.

It goes without saying that the authors' writings are inspired and at least partially informed by their own experiences as a girl, a wife, and by their educational background and/or career as a political activist and their acquaintance with Western (literary and feminist) theories and conceptions.

\section{Biographical Sketch of the Selected Authors}

Alifa Rifaat is the pen name of Fāțima ('Abd Allāh) Rif'at who was born into a wealthy family of landowners in Cairo in $1930 .{ }^{2}$ She is the only one of the three authors who was not allowed to study, although she had wanted to enrol in the College of Fine Arts after finishing secondary school. Instead her father married her off to her maternal uncle's son, a police officer. ${ }^{3}$ Rifaat published her first short story in 1955. When her husband was against it, she went on publishing under a pseudonym until in 1960 she had to stop under threat of being divorced

1 On the theme of alienation and madness in Arab Women's literature cf. Chapter 6 entitled Narratives of Alienation and Descent into Madness [in:] D. Abudi, Mothers and Daughters in Arab Women's Literature: The Family Frontier, Leiden-Boston 2011, in which the author analyses two recent novels in greater detail. For her general remarks cf. pp. 221-231 in particular.

2 On her life and work cf., for instance, Crosshatching in Global Culture: A Dictionary of Modern Arab Writers: An Updated English Version of R. B. Campbell's “Contemporary Arab Writers", ed. J.J. Donohue, L. Tramontini, Vol. 2, Beirut 2004, pp. 937-940 (includes autobiographical notes by the author); A. Rifaat, Zeit der Jasminblüte: Erzählungen aus dem Arabischen von Nagi Naguib, Zürich 1988, pp. 136-141.

3 But it is said that she trained herself by reading on a wide range of topics. 
and separated from her children. ${ }^{4}$ Only after she had fallen seriously ill did her husband permit her to go back to writing and publishing as from the mid-1970s. Following the death of her husband in 1979, Denys Johnson-Davies who was the first to translate some of her short stories into English, ${ }^{5}$ encouraged her to change her style by abandoning some of the romantic aspects and to write the dialogues in colloquial language. Altogether, Rifaat has published more short stories than novels. As she spent a great part of her life in provincial Egypt, rural Egypt became the setting for many of her stories.

The prominent Egyptian feminist Nawal El Saadawi (Nawāl [as-Sayyid] asSa 'dāwī) was born into a middle-class family in a small village in the Nile Delta in 1931 and studied medicine with a specialisation in psychiatry in Cairo and New York. ${ }^{6}$ As she began her life as a practising physician in the Egyptian countryside, she witnessed the misery of the poor peasants. In addition, her strong ties to her father's poverty-stricken relatives in the countryside broadened her knowledge of the situation in rural areas. These experiences are reflected in her writings. Her first collection of short stories appeared in 1961. In all, Saadawi published about fifty works of fiction and non-fiction, including novels, plays, short stories, and autobiographical texts. She married three times, ${ }^{7}$ and is the mother of one daughter and one son. Her writings have stirred up a considerable controversy; her unyielding demands for women's rights and her outspoken disclosure and critique of the defects of her society, especially those associated with the multiple facets of patriarchy, have not only led to denunciations, polemics and smear campaigns against her but also to her dismissal from the Ministry of Health (1971), her imprisonment (1981), the banning of her books and of the women's organisation founded and presided over by her (1991), death threats, exile (1993-96), and a flurry of court cases. Despite all this Saadawi has continued her fight against all forms of discrimination.

Salwa (Salwā) Bakr was born in 1949 to a lower-middle-class family in Cairo. ${ }^{8}$ Her father, a railway employee, died before her birth. The life and fate of her mother was to be of crucial importance for her later writings in which the poor and uneducated, with their worldview and their styles of speech figure prominently. Through her mother, a woman from Upper Egypt by origin who had to leave school when she reached puberty in order to protect her reputation by agreeing to an early, arranged marriage, Bakr became acquainted with the precarious situation of widowed, divorced or unmarried women who had to rely entirely on their own

4 In all, she had three sons who survived her.

5 A. Rifaat, "Distant View of a Minaret" and Other Stories, trans. D. Johnson-Davies, London 1983.

6 For details on her life and work, cf., e.g., Crosshatching..., ed. J.J. Donohue, L. Tramontini, pp. 968-973; D. Royer, A Critical Study of the Works of Nawal El Saadawi, Egyptian Writer and Activist, Lewiston-New York 2001, pp. 9-27; F. Malti-Douglas, Men, Women, and God(s): Nawal El Saadawi and Arab Feminist Poetics, Berkeley 1995, pp. 9-19 and passim.

7 Her third husband, Sherif Hetata, translated many of her works into English.

8 On her life and work, cf. C. Seymour-Jorn, Cultural Criticism in Egyptian Women's Writing, Syracuse-New York 2011, pp. 18-55; R. El-Enany, The Madness of Non-Conformity: Women Versus Society in the Fiction of Salwā Bakr, "Journal of Arabic Literature" 2006, Vol. 37, No. 3, pp. 376-415. 
wits and resources to get by in life. Unlike her mother, Bakr was able to finish her education and to study at the Cairene 'Ayn Shams University. She obtained a bachelor's degree in Business management (in 1972) first, then in Theatre (1976), and later she pursued studies in history and literature. Her early professional experience as an inspector for the Ministry of Supply in Cairo from 1974 to 1980 not only provided her with insights into the economic difficulties, but also introduced her to the political actions of poor Cairene women, as she witnessed the outbreak of the 1977 bread riots. Except for the five years she lived in Lebanon and Cyprus where she worked as a theatre, film, and literary critic and met her husband, ${ }^{9}$ she has spent most of her adult life in Cairo. She has published about twenty literary works, above all short story collections and novels. ${ }^{10}$

\section{The Plight and Fate of Socially Marginalised Women Narrated from Three Different Perspectives}

Unlike her colleagues, Rifaat focused her writing on women in traditional roles. Her female protagonists in most cases resign themselves to the hardships they face in life, as being God given. Often, they seek refuge in religion, magical practices, mysticism, and phantasies to cope with their situation. Several of her stories handle controversial topics such as sexuality, clitoridectomy, teenage pregnancy, arranged marriage, and domestic violence. ${ }^{11}$ In Bahiyya's Eyes (1983), one of her most popular stories, the aged Bahiyya (also a name for Egypt) explains to her daughter why she wished to see her once again before completely losing her eyesight. Contrary to the doctor's diagnosis that the problems with her eyes are due to natural causes (flies and dirt), she is convinced that they are caused by all the tears she has cried because of her life as a woman. "The fact is there's no joy for a girl in growing up; it's just one disaster after another, till you end up an old woman who's good for nothing and who's real lucky if she finds someone to feel sorry for her". ${ }^{12}$ In what follows, she recounts her childhood, her circumcision, the

\footnotetext{
9 They have two children.

10 Some of her publications have also been translated into English and German. For a list of her publications cf. C. Seymour-Jorn, Cultural Criticism ..., p. 22, n. 3; R. El-Enany, op. cit., pp. 414-415.

11 Including death as a result of domestic violence, cf. A. Rifaat, Die Mädchen von Burdain, Zürich 1995 (quotation on p. 38, own trans.): One of the farmer's wives dies after he had beaten her; she had a miscarriage and finally bled to death. Shortly after the funeral he marries again, a younger woman. While looking at the mostly young children of the deceased mother, one of the female mourners at the funeral whispers in the ear of another woman: "Oh God! Those who lose their mother are really orphaned. I am quite certain that he will marry again. Do men know at all what sorrow and loyalty means? Had he died, the poor woman would have devoted her youth as a widow to the upbringing of the young children. But the men ...?" - Indifference and emotional coldness between spouses is another recurrent topic in Rifaat's work.

12 A. Rifaat, "Distant View of a Minaret"..., p. 8. For the translation of the whole story: ibid., pp. 5-11. For an analysis of the story cf. R.M. Salti, Feminism and Religion in Alifa Rifaat's Short Stories, "The International Fiction Review" 1991, Vol. 18, No. 2, pp. 110-111; N. El Miniawi, Religion and Feminism in the Short Story of Alifa Rifaat - The Voice of the "Voiceless", "Journal of Literature and Art Studies" 2013 (July), Vol. 3, No. 7, pp. 405-406, 409, 411.
} 
beatings of the Sheikh at the Koranic school, her arranged marriage, her early widowhood, the hardships of raising children as a single mother. She also speaks of her growing loneliness in the village after her sister and brother had moved to another location and her isolation because the married village women are used to regarding widowed women as a potential threat and therefore avoid contact with them. However, she later on also remembers the rare joyful moments while playing alongside the water canal, making figures in clay, and her first innocent love for a village boy. In the end, she does not regret that God created her as a woman, but, "It's just that I'm sad about my life and my youth that have come and gone without my knowing how to live them really and truly as a woman". ${ }^{13}$ This last statement can be regarded as a kind of maternal legacy to the daughter, and at the same time as the hope that the next generation will have a happier and more fulfilled life.

It is true that most of Rifaat's stories revolve around a woman's right to a fully emotional and sexual life in marriage. ${ }^{14}$ But they not only deal with male oppression of females in the form of denial of education, physical violence, and restrictions, but also demonstrate the senior female complicity in the oppression by supporting constraints on girls and younger women and by justifying the male privilege in the name of the status quo. ${ }^{15}$ The loss of childhood and adolescence marked by circumcision and arranged marriage is a recurrent topic. Moreover, her stories sometime address the issue of child labour due to poverty, ${ }^{16}$ and even more often the elders' and parents' indifference to and lack of understanding of children's wishes. Children in general, but especially girls are prevented from

13 A. Rifaat, "Distant View of a Minaret"..., p. 11.

14 Her boldness in presenting women's sexual desires, which raised criticism from conservative forces (R.M. Salti, op. cit., p. 109), is still considered unusual.

15 For rare instances of female solidarity see the following two short stories: In An Incident in the Ghobashi Household a village woman devises a plan to save the life of her teenage daughter who has got pregnant outside the bond of marriage. She gives her daughter all her savings and instructs her to go to Cairo and stay there until the baby is born. The mother for her part simulates her own pregnancy in wrapping old rags around her waist in order to prevent the tragedy of honour crime, saying to her daughter: "Isn't it better, when he [i.e. the father who has found work for a year in Libya] returns, for your father to find himself with a legitimate son than an illegitimate grandson?" (A. Rifaat, "Distant View of a Minaret"..., pp. 23-27, quotation on p. 27). In The Honour, the discretion of the younger sister and the (paid) help of the village's midwife avoid a scandal (and probably an "honour killing") during the wedding night of the older sister (Die Ehre [in:] A. Rifaat, Erste Liebe - letzte Liebe: Erzählungen, Berlin 1989, pp. 127-140).

16 Cf. "The harbinger of bad luck" (Die Unglücksbringende [in:] A. Rifaat, Erste Liebe..., pp. 95-106) in which the mother regards her little daughter as the "harbinger of bad luck" because she associates her with the death of her husband and the hardship she has had to endure as a young widowed woman with a handful of little children. The mother is happy when she gets the chance to sell the little troublemaker against the girl's will as a 'nanny' to the household of a wealthy family. Finally, the little girl, who feels lonely and yearns for her mother, her siblings, and the freedom to run through the fields, and who - against the agreement made - also has to work in the kitchen, escapes with one of the precious toys belonging to the wealthy children, which she is not allowed to touch. But, it is of no avail. She is brought back by her mother to the rich household, after the mother has begged the lady in abject submission to let her resume her work and after the child has been punished for her unacceptable, "ungrateful" behaviour. 
developing their own personal identity, and their potential and talents are ignored by a society that seeks to silence, distance, and ostracize any woman for social transgressions.

Already in the mid-1970s Saadawi had reached out and explored beyond Rifaat's mental approach. In Mawt ar-rağul al-wahìd 'alā al-arḍ ${ }^{17}$ she highlighted the complex mechanisms of the patriarchal system that foster and perpetuate the problems faced in particular by girls and women by exposing the interplay of political, economic, social, religious and cultural facets of oppression. The nature of power relations in country regions, and by extension, in the wider society in Egypt, shows the hypocritical use of religion and the influence of superstition.

The story is set in a village on the banks of the Nile, and first and foremost relates the tragedy of Zakeya, the main female character, and of her family, all of whom are ruined by the omnipotent mayor and his lackeys (the Imam of the mosque, the barber, and the head of the village guard). The mayor, whose authority is above law, religion, and moral values, defiles each of Zakeya's nieces (under false pretences), and frames her brother and son for crimes they have not committed. After the loss of all the members of her family Zakeya takes revenge and kills the mayor. In jail, she says to a fellow inmate that she "buried him [Allah] on the bank of the Nile". ${ }^{18}$ By him she means the mayor in the literal sense, but also that God is dead to her because of all the misery she and her family have been through. Already before this last scene, the reader has come to know that Zakeya has lost faith in God and resigned herself to her fate. When her younger niece Zaynab, who at that moment was still clinging to religion, encouraged her aunt to pray, Zakeya answered calmly, "I have not ceased praying and begging God to help us. And yet everyday our misery becomes greater, and we are afflicted with a new suffering". ${ }^{19}$

As a whole, the novel is an outright criticism of an immoral, corrupt, and hypocritical government figure (the mayor who rules and controls the village) and his partners in crime, who feel no sense of responsibility for the village community and no empathy for the hard-working peasants. In contrast to early Egyptian novels, Saadawi does not romanticise village life, nor does she glorify the peasant. The villagers' life is depicted as harsh, unfair, and unforgiving. And although the majority of the villagers are victims of the evil doings of the mayor, they themselves sometimes become oppressors. Their ignorance and their cultural and religious socialisation often result in scapegoating and even mob violence.

The lack of personal freedom as a result of restrictive social attitudes, the oppression of the poor due to economic policies, government corruption, and the hypocrisy of those who wield power and authority have become common topics in much of modern Egyptian literature, and they are also themes that figure prominently in Bakr's work. The originality of Bakr's narratives, however, lies in the

17 Literally, "Death of the only man on earth" (Beirut 1976), here cited according to the Engl. trans. God Dies by the Nile (London 1985) by Sherif Hetata. For a discussion of the novel cf. D. Royer, op. cit., pp. 117-138.

18 N. El Saadawi, God Dies..., p. 138.

19 Ibid., p. 67. 
way she works to unveil the irrationality of the dominant patriarchal logic. A major theme in her writings, for instance, is her challenging of the allegedly clear difference between sanity and lunacy in that girls or women who resist or transgress the norms and values of society, or behave in a way that does not conform with generally undisputed standards, are frequently labelled crazy, mad, or abnormal. Her stories often suggest instead that in fact those who call the "deviants" crazy or mad, are the really abnormal people or lunatics. Accordingly, the characters she portrays in her narratives are complex, and the plots not only demonstrate the various factors that affect women's lives and may drive them to the brink of madness, but also depict the women as both victims and agents. Moreover, Bakr employs humour and sarcasm as a means of criticising social conditions. Apart from experiments with language and narrative techniques, ${ }^{20}$ another feature of Bakr's stories is that most of her protagonists, who live on the fringes of society, demonstrate agency, common sense, and something like natural wisdom and political insight. Zīnāt in Zinat in the President's Funeral (1986) ${ }^{21}$ is a good case in point as also Umm Šiḥta in Umm Šihta Who Brought Matters to a Head in the same collection. ${ }^{22}$

A fine example for her questioning of the common categorisation of normal versus abnormal is Bakr's short story Dotty Noona ${ }^{23}$ about a sensitive and inquisitive girl who prefers to run away when confronted with her father's decision to marry her off. After a sleepless night, she swears that "she did not want to return to the village and to live amidst dirt and fleas and mosquitoes; she also did not want to marry, to become - like her sisters - rooted in suffering". ${ }^{24}$ This illiterate girl from the countryside had been sent to Cairo at the age of ten to work as a maidservant for the wealthy family of an officer. During her three years living there she would listen in on the classes in the school opposite the kitchen while she was busy with cleaning and cooking. She kept repeating and imitating the girls during their exercises, and thus gained some knowledge. The lady of the house thought Noona was a bit strange ("dotty") because she was unable to understand the girl's thirst for knowledge and education. Maybe she was also still shocked that the peasant

20 For these characteristics of Bakr's work see, in particular, the publications of C. Seymour-Jorn, A New Language: Salwa Bakr on Depicting Egyptian Women's Worlds, "Critique: Critical Middle Eastern Studies" 2002, Vol. 11, No. 2, p. 160-170 and passim; eadem, Cultural Criticism..., pp. 24-28, 51-52.

21 An English translation was provided by M. Booth, My Grandmother's Cactus: Stories by Egyptian Women, introd. and trans. M. Booth, London 1991 under the title Zeenat Marches in the President's Funeral, pp. 24-37. Zinat constantly writes petitions with the help of her friend, the barber, to the president [Nasser] talking about her problem, asking for an increase of her insufficient pension. For an analysis of the short story cf. R. El-Enany, op. cit., pp. 378-379.

22 Umm Šihta, the heroine of the short story, is a washerwoman who leads a popular uprising during the bread riots of 1977 . Her courage, political acumen, and cleverness are contrasted with the leftist intellectual who only repeats slogans. For remarks on this story cf. also R. El-Enany, op. cit., pp. 379-380.

23 S. Bakr, "The Wiles of Men" and Other Stories, transl. D. Johnson-Davies, London 1992, pp. 41-48. The story is analysed by R. El-Enany, op. cit., pp. 381-382. The story of Dotty Noona (in Arabic Nüna ă̌šsa 'nūna) was later adapted for an Egyptian television film.

24 S. Bakr, "The Wiles of Men"..., p. 48. 
girl had once been able to solve a math problem better than her son. It is striking that none of the few people who ever met Noona was able to describe her features when asked about the runaway by the public attorney. They did not even call her by her proper name but rather by the name given to her by the lady, whereas the girl herself loved her real name $\mathrm{Na}$ 'ima, and also her pet name $\mathrm{Na}^{\text {'ouma, and }}$ found nothing nice about the name Noona. ${ }^{25}$

While the author leaves the fate of "Noona" open, the reader of Arabic fiction might remember, for instance, the fate of young women in Saadawi's novels, who when walking unaccompanied on the street, would be prey to sexual abuse - as it happened to the main character of Woman at Point Zero, Firdaws, or, as it is suggested in the case of Zaynab in God Dies by the Nile.

In Imra'a 'inda nuqtat aș-șifr ${ }^{26}$ the narrator meets Firdaws on the eve of her execution for murdering a pimp, and the largest portion of the book is Firdaws' life story, a first-person account of how a young girl from humble background, sexually molested and abused since her childhood, a victim of family intrigues, forced marriage with an old man, intimate violence, finally turns to prostitution, at first unwillingly, then willingly. When she becomes quite successful, a pimp forces her under his control. She kills him when he attacks her and wants to beat her up yet again. In fact, she had acted in the heat of the moment, in self-defence; but when she later confesses the act to a new customer, a prince, he calls the police, and in jail she refuses to write a petition; as she asserts, "I want nothing. I hope for nothing. I fear nothing. Therefore[,] I am free. For during life[,] it is our wants, our hopes, our fears that enslave us". ${ }^{27}$

The best example for the deconstructionist approach to the topic of alleged madness of women, among the authors discussed here, is Bakr's well-known novel The Golden Chariot Does Not Ascend to Heaven ${ }^{28}$ which is set in a women's prison on the outskirts of Cairo ${ }^{29}$ and narrates the life stories of a number of inmates, who have committed various crimes ranging from theft and drug dealing to prostitution and murder. The framework of the story is formed by the plan of the central character, Aziza, to leave the prison in a 'golden carriage'. As Aziza has to decide whom to take with her and whom to leave behind, she has to become ac-

25 Ibid., p. 46.

26 Orig. published: Beirut 1975; N. El Saadawi, Woman at Point Zero, trans. S. Hetata, London 1983. For a detailed discussion of the book, cf. D. Royer, op. cit., pp. 91-116; F. Malti-Douglas, op. cit., pp. 44-67; R. Saiti, Paradise, Heaven, and Other Oppressive Spaces: A Critical Examination of the Life and Works of Nawal El-Saadawi, "Journal of Arabic Literature" 1994, Vol. 25, pp. 154-159.

27 N. El Saadawi, Woman at Point Zero, p. 101.

28 Al-Araba ad- $\underline{d}$ dahabiyya lā taș 'ad ilā as-samā' (Cairo 1991), English translation: The Golden Chariot, trans. D. Manisty, United Kingdom 1995. For a more detailed discussion of the novel cf. D. Manisty, Madness as Textual Strategy in the Narratives of Three Egyptian Women Writers, "Alif: Journal of Comparative Poetics" 1994, Vol. 14, pp. 163, 164-165; C. Seymour-Jorn, Cultural Criticism..., pp. 28-36; R. El-Enany, op. cit., p. 387-391; N. Sinno, From Confinement to Creativity: Women's Reconfiguration of the Prison and Mental Asylum in Salwa Bakr's "The Golden Chariot" and Fadia Faqir's "Pillars of Salt", "Journal of Arabic Literature” 2011, Vol. 42, No. 1, pp. 71-77, 82-84, 86-89, 92.

29 Like Saadawi, Bakr had been arrested for a short time and therefore had experienced life in an Egyptian women's prison. Cf. R. El-Enany, op. cit., p. 389, n. 30. 
quainted with the life stories of her fellow inmates. During this selection process, some women will break silence for the first time and dare to articulate the pains and humiliations they have had to endure. By exposing and exploring the unbearable social and economic hardships, and the underlying psychological factors that have led to the particular offences, Bakr demonstrates that it was social injustice that has driven the women to commit crimes and/or resort to violence rather than an inherent criminal instinct or even psychotic illness, although the persons concerned experience temporary mental and emotional disorders as a result of their traumatic pasts. Some of the prisoners have not even committed any crime: they have taken the blame for the crimes of male relatives. While the minority of the prisoners has a privileged family background, such as the central protagonist Azi$\mathrm{za}$, the overwhelming majority comes from the lower social strata. Umm Ragab, divorced only a few months after her marriage, and Safiyya, originally a runaway orphan abused by her stepfather, illustrate the potential socio-economic roots of a criminal career: they had worked in unskilled jobs in order to feed themselves and their family before they discovered more or less by chance their talent for pickpocketing. After their first success, they even felt a delight, a sense of regaining energy or even self-esteem. Safiyya finally ended up as a drug dealer in order to satisfy her growing addiction to foreign consumer goods. Other life stories prove that not only economic pressures but also sexual abuse and other forms of exploitation and manipulation may push women to commit crimes..$^{30}$

Being shielded from the outside world, from the pressures of daily life and the prejudices of society, gives at least some inmates the opportunity for selfreflection and for a questioning of pre-conceived ideas. Although prison life is not idealised, because biases, conflicts, and injustices are still present, the place of confinement is turned into a space of creativity and transformation which for some prisoners leads to self-realisation and (re-) discovery of their hidden talents. What is more, for the first time the inmates experience a kind of female solidarity they have never known before.

That also small, harmless longings and wishes may be labelled mad and even end tragically, is shown in Bakr's short story Thirty-One Beautiful Green Trees. ${ }^{31}$ In it, the protagonist Karima, a young woman of the lower middle-class who initially only wishes to have more beauty, colours and plants in her otherwise dull and grey everyday life, eventually ends in the lunatic asylum. ${ }^{32}$ There she writes

30 Aziza, for instance, was seduced by her stepfather as a child and became his lover. Several years after the death of her blind mother he decided to marry the daughter of his favourite friend. Aziza felt betrayed, because she had rejected numerous marriage offers in the hope to becoming his wife. She takes revenge in murdering him. For other examples see the stories of Hinnah, Huda, or Zaynab as summarised by R. El-Enany, op. cit., pp. 388-389, n. 29.

31 For an English translation cf. S. Bakr, "Wiles of Men"..., pp. 12-26. For a discussion of this short story cf., e.g., R. El-Enany, op. cit., pp. 383-385; D. Manisty, op. cit., pp. 158-160.

32 In contrast to a short story by the late Egyptian professor for English literature Radwa Ashour (1946-2014), entitled "I saw the Date Palms" (Ra'ayt an-nahl, originally published in a magazine in 1987), in which the efforts of the protagonist Fawziyya, who is addicted to planting, but rather inconspicuous, finally are not lost. Fawziyya had moved from a village in Upper Egypt to Cairo after her parents and brothers had died. She is depicted as an isolated woman. It is only when her aunt 
down her story because nobody wanted to listen to it, still less to try to understanding her behaviour. In the beginning Karima is concerned about the gradual destruction of the once beautiful city of Cairo which is symbolised by the cutting of thirty-one trees that shaded a street in her neighbourhood. As a highly sensitive woman, the loss of the trees disturbs her. In addition, Karima's human aspirations for freedom, self-expression and creativity are not appreciated, her efforts to brighten the shabby office she is working in, is met with incomprehension by her colleagues. The situation escalates on the day of election when she dares to ask the candidates about their ecological program and about the lack of women candidates. As a result, her identity and voter's registration card are taken and she is attacked. Back home her mother reproaches her for her behaviour saying it might threat the career of her brother, an officer. Her mother adds, "Won't you ever stop your silliness and hold your tongue? By Allah, you deserve to have it cut out". ${ }^{33}$ After berating herself, Karima decides to cut off her tongue so that she will be able to stop talking and avoid trouble. ${ }^{34}$ Though she does not succeed in this endeavour, the implications are lasting. She is forced into the asylum but the nurses and doctors do not understand the reason for her attempted self-mutilation.

Voicelessness is a recurring theme throughout Bakr's writings and perhaps it is best reflected in The Beautiful Undiscovered Voice..$^{35}$ The protagonist, a married, exhausted housewife, mother of two, suddenly notices that she has a melodious voice. Yet nobody in her direct environment believes her, or is willing to listen to her newly discovered talent. Her husband takes her to the doctor, who prescribes tablets. When the woman realises that her beautiful voice which has given her joy and new energy has gone, she flushes the pills down the lavatory - her (allegedly) last act of self-determination.

brings her a branch from her grandmother's cactus (a symbol of continuity, life and hope, representing the female line, whereas the date palm represents the tradition of her family) that Fawziyya rediscovers the pleasure of planting and starts to plant anything from date stones discarded by passers-by, to mint cuttings, or jasmine although she is living in only one room with a small balcony. At work and in the neighbourhood, however, her behaviour is identified as strange or even mad. She is ridiculed in the public (by young boys). In the end, the old cactus still bears green leaves, and a neighbour comes to visit her and asks Fawziyya to teach her how to grow plants because she has noticed and admired the flowerpots on the balcony. - For an English translation of the story cf. M. Booth, op. cit., pp. 147-155. For a detailed analysis of the story cf. D. Manisty, op. cit., pp. 155-158. For a short obituary on the famous author cf. Egyptian Writer Radwa Ashour Dies at 68, "Ahram Online" 2014, 1 December, http://english.ahram.org.eg/NewsContentP/18/116873/Books/Egyptian-writer-Radwa-Ashour-dies-at-. aspx (access: 13.06.2016).

33 This is a slightly modified version of the translation in S. Bakr, "Wiles of Men"..., p. 24.

34 Karima encourages herself to cut the tongue by comparing it to her circumcision (ibid., p. 25). Before, she recalled that her mother once in her childhood threated to cut her tongue because she had divulged a secret to her father (ibid., p. 24).

35 For an English translation cf. S. Bakr, "Wiles of Men”..., p. 57-70. The story is discussed by D. Manisty, op. cit., pp. 160-162. 


\section{Conclusion}

In a rough categorisation, we can distinguish three different approaches to the subject of socially marginalised women as exemplified here in selected works of three women writers. Whereas Rifaat follows a more descriptive approach Saadawi's approach can be termed structuralist and Bakr's deconstructivist. Although it is the intention of all three authors to raise awareness about the deprivation, the needs and the feelings of women on the fringes of society, Rifaat particularly describes the marginalising, alienating and isolating effects of a male-centred society; Saadawi concentrates on highlighting the way the political, economic, social, religious, and cultural factors that promote male domination and female oppression intersect; and the underlying preoccupation of authors like Bakr is to expose the irrationality of patriarchal logic, and by questioning its legitimacy to demonstrate ways to self-realisation and self-development. Accordingly, the protagonists of the three authors are correspondingly depicted as more passive, more active or more subversive. Bakr also makes greater use of symbolism and surrealism, and of a broader repertoire of narrative techniques.

Naturally this rough perception of a pattern refers to the authors' different main tendency and does not mean that there are no indications at all of other or overlapping perspectives in the works of these three women authors. The focus of the individual writers can be at least partially explained by their own personal experience in life and work. Saadawi and Bakr are more outspoken in their criticism of the society. ${ }^{36}$ However, like Rifaat, Saadawi as a feminist of the older generation seems to be more strongly influenced by a binary gender coding than Bakr.

\section{Bibliography}

Abudi D., Mothers and Daughters in Arab Women's Literature: The Family Frontier, Leiden-Boston 2011.

Bakr S., "The Wiles of Men" and Other Stories, transl. D. Johnson-Davies, London 1992.

Bakr S., The Golden Chariot, transl. D. Manisty, United Kingdom 1995.

36 This is true for their comments on the situation in Egypt before the "revolution of $25^{\text {th }}$ of January" 2011 as well as during its aftermath, with all the unfulfilled expectations regarding hopes of a change in gender relations, socio-economic misery, and political structure. Cf., e.g., A. Fariborz (Interview with N. El Saadawi), “They Don't Want Really Courageous People”, "Qantara” 2014, 7 May, https://en.qantara.de/node/17816 (access: 13.02.2017); Nawal El Saadawi: 'Do you Feel You Are Liberated? I Feel I Am not', "The Guardian" 2015, 11 October, https:/www.theguardian.com/ books/2015/oct/11/nawal-el-sadawi-interview-do-you-feel-you-are-liberated-not (access: 13.02.2017); C. Mende Claudia, Profile of the Egyptian Writer Salwa Bakr: The Voice of the Marginalized, "Qantara" 2012, 24 September, http://en.qantara.de/node/2554 (access: 20.06.2016); E. Chalala, Novelist Salwa Bakr Dares to Say it Aloud, "Al Jadid" 2015, Vol. 19, No. 68, http://www.aljadid.com/content/novelistsalwa-bakr-dares-say-it-aloud (access: 20.06.2016). 
Chalala E., Novelist Salwa Bakr Dares to Say it Aloud, “Al Jadid”2015, Vol. 19, No. 68, http://www.aljadid.com/content/novelist-salwa-bakr-dares-say-it-aloud (access: 20.06.2016).

Crosshatching in Global Culture: A Dictionary of Modern Arab Writers: An Updated English Version of R. B. Campbell's “Contemporary Arab Writers”, ed. J.J. Donohue, L. Tramontini, Vol. 2, Beirut 2004.

Egyptian Writer Radwa Ashour Dies at 68, “Ahram Online” 2014, 1 December, http:// english.ahram.org.eg/NewsContentP/18/116873/Books/Egyptian-writer-RadwaAshour-dies-at-.aspx (access: 13.06.2016).

El-Enany R., The Madness of Non-Conformity: Women Versus Society in the Fiction of Salwā Bakr, "Journal of Arabic Literature" 2006, Vol. 37, No. 3.

El Miniawi N., Religion and Feminism in the Short Story of Alifa Rifaat - The Voice of the "Voiceless", "Journal of Literature and Art Studies" 2013 (July), Vol. 3, No. 7.

El Saadawi N., God Dies by the Nile, transl. S. Hetata, London 1985.

El Saadawi N., Woman at Point Zero, transl. S. Hetata, London 1983.

Fariborz A., "They Don't Want Really Courageous People” (an interview with N. El Saadawi), “Qantara” 2014, 7 May, https://en.qantara.de/node/17816 (access: 13.02.2017).

Malti-Douglas F., Men, Women, and God(s): Nawal El Saadawi and Arab Feminist Poetics, Berkeley 1995.

Manisty D., Madness as Textual Strategy in the Narratives of Three Egyptian Women Writers, "Alif: Journal of Comparative Poetics" 1994, Vol. 14.

Mende C., Profile of the Egyptian Writer Salwa Bakr: The Voice of the Marginalized, "Qantara" 2012, 24 September, http://en.qantara.de/content/profile-of-the-egyptian-writer-salwa-bakr-the-voice-of-the-marginalized (access: 20.06.2016).

My Grandmother's Cactus: Stories by Egyptian Women, introd. and transl. M. Booth, London 1991.

Nawal El Saadawi: 'Do You Feel You Are Liberated? I Feel I Am not', "The Guardian” 2015, 11 October, https://www.theguardian.com/books/2015/oct/11/nawalel-sadawi-interview-do-you-feel-you-are-liberated-not (access: 13.02.2017).

Rifaat A., "Die Mädchen von Burdain ". Aus dem Arabischen von Regina Karachouli, Zürich 1995.

Rifaat A., "Distant View of a Minaret" and Other Stories, transl. D. Johnson-Davies, London 1983.

Rifaat A., "Erste Liebe - letzte Liebe: Erzählungen". Aus dem Arabischen von Suleman Taufiq, Berlin 1989.

Rifaat A., Zeit der Jasminblüte: Erzählungen aus dem Arabischen von Nagi Naguib. Mit e. Nachwort des Übersetzers, Zürich 1988.

Royer D., A Critical Study of the Works of Nawal El Saadawi, Egyptian Writer and Activist, Lewiston-New York 2001.

Saiti R., Paradise, Heaven, and Other Oppressive Spaces: A Critical Examination of the Life and Works of Nawal El-Saadawi, "Journal of Arabic Literature" 1994, Vol. 25.

Salti R.M., Feminism and Religion in Alifa Rifaat's Short Stories, "The International Fiction Review" 1991, Vol. 18, No. 2.

Seymour-Jorn C., A New Language: Salwa Bakr on Depicting Egyptian Women's Worlds, "Critique: Critical Middle Eastern Studies" 2002, Vol. 11, No. 2. 
Seymour-Jorn C., Cultural Criticism in Egyptian Women's Writing, Syracuse-New York 2011.

Sinno N., From Confinement to Creativity: Women's Reconfiguration of the Prison and Mental Asylum in Salwa Bakr's "The Golden Chariot" and Fadia Faqir's "Pillars of Salt”, "Journal of Arabic Literature" 2011, Vol. 42, No. 1. 